\title{
Formation of rice plants productivity traits in first generation hybrids and their inheritance
}

\author{
Irina Chukhir ${ }^{1, *}$, Nikolay Chukhir ${ }^{1}$, and Diana Belik ${ }^{2}$ \\ ${ }^{1}$ Federal Scientific Rice Centre, group of initial material, Russia \\ ${ }^{2} \mathrm{KubSAU}$, faculty of agrochemistry and plant protection, Russia
}

\begin{abstract}
Rice is the oldest and widespread food crop, which is a staple food in many countries such as India, Japan, China, Vietnam. Milled rice has a balanced amino acid composition, excellent taste, is highly digestible and assimilable, it is widely used, in general, and dietary nutrition, and its broth has healing properties. Derivatives produced from cereals are widely used in the textile, perfumery, and medical industries. The straw is used to feed livestock and make household goods. Huge shifts have taken place in recent years in domestic and foreign rice cultivation, varieties of various purposes and uses have been developed and are cultivated, but, despite this, there are still many unsolved urgent problems. The main of these problems is the development of high-yielding varieties, which are greatly influenced by economically important traits: plant height, total and productive tillering, the number of spikelets and grains in a panicle, grain size, mass of 1000 grains, etc. The solution to this problem largely depends on the availability of genetically diverse initial material with a broad response to changes in environmental conditions, its study and correct selection; as well as the identification of new sources of valuable traits and properties, among ecologically distant agroecotypes, which enrich the genetic potential of domestic varieties. In the modern biological science of heredity, there is still the question of the inheritance of quantitative traits. The study of the inheritance of quantitative traits that make up the main elements of the yield structure is one of the most important tasks, the solution of which is necessary to accelerate the breeding process. The inheritance of any trait is often determined by researchers by the value of the dominance coefficient [7].
\end{abstract}

Breeding, as the science of developing new varieties and hybrids, is inextricably linked with seed production and botany. The theoretical basis for breeding is genetics with its laws of heredity and variability of organisms. For more effective methods of developing varieties and hybrids, it is necessary to study the genetic and breeding value of various cultivated and wild species - carriers of economically valuable traits, to make wider use of the possibilities of biotechnology, to improve the methods of intraspecific, complex stepwise and distant hybridization. For this, it is necessary to identify genes and groups of genes that control economically valuable traits, study the patterns of their inheritance, patterns of interaction between the genotype and the environment, study the genetic and physiological

* Corresponding author: irina-chukhir@mail.ru 
and biochemical foundations of the phenomenon of heterosis effect. The most important tasks of breeding should also include the study of genetic and physiological - biochemical bases of the influence of biotic and abiotic factors on plants in order to develop methods that allow combining these important biological properties with high productivity in future varieties.

In practical breeding, it is often necessary to know the behavior of rice hybrids, the pattern of inheritance of economically valuable traits and their variability. By inheritance, it is customary to understand the transfer of parental traits and properties to progeny. Usually, hybrid populations form highly heterotic plants, which have increased values in relation to the parental forms. With individual selection in nurseries, breeders visually select genotypes that are qualitatively different and superior to the parental forms, that is, with a heterotic effect. Under the heterotic effect [4] it is customary to understand the average value of the hybrid which, according to this trait, goes beyond the boundaries of the average value of the best parent individual. When plants appear significantly superior to the parental forms in the hybrid population, they indicate the manifestation of the transgression $[1,7]$. Breeding work and its success largely depend on a deep analysis of the traits transmitted to hybrid progeny from parental forms, and the patterns of their variability in the second and subsequent generations, as well as the selection of the best plants for reseeding for the next year is of great importance. How effective the selection was, and whether the same magnitude of manifestation of the trait will remain the same next year has always been important for researchers.

It is known from many literary sources that the proportion of homozygotes increases, and the proportion of heterozygotes decreases from generation to generation, independently from inherited traits, which are subject to selection [11,12]. Therefore, in the second generation, the proportion of homozygotes will be exactly $50 \%$, in the third generation $75 \%$, and in the fourth $-87 \%$, and the proportion of heterozygotes in $\mathrm{F}_{4}$ will be $12.5 \%$ of the total number of plants. Knowing these patterns, it is possible to carry out individual selections starting from the second generation.

For many years, hybridization has been the main or basic method for developing initial and breeding material [2]. Parental forms included in hybridization must have a complex of traits that will characterize the variety. Each trait is controlled by the necessary genes or a complex of genetic factors that make up the genotype of the developed variety $[4,5,7]$.

When breeding new rice varieties in recent years, priority has been given to the including genotypes possessing valuable genes for resistance to abiotic and biotic environmental factors into crossings. Using for these purposes samples or varieties with alternative traits, and considering this as a result of a complex interaction in a hybrid organism of genetic, cytoplasmic, biochemical and physiological factors [1] in hybrid combinations, high values of such characteristics can be obtained.

The aim of the research was to study the quantitative traits controlling the productivity of plants using the values of the dominance coefficient, as well as their inheritance.

The selected parental pairs and the $F_{1}$ hybrids obtained after crossing were grown in the phytotron complex of the centre [3,8-10]. During the full ripeness phase, biometric analysis was carried out in the combinations that had shown a heterotic effect.

We selected 50 out of 250 distinguished combinations, which were further studied in a hybrid nursery on a vegetation site. During the study, some combinations were rejected. From 50 studied plots, 10 hybrid combinations were selected, which were sown in a hybrid nursery of older generations in the field, on plots length of which was $10 \mathrm{~m}^{2}$.

From each hybrid combination, 15 plants were selected for biometric analysis. Hybrids of the second generation were studied in comparison with the parental forms and first generation hybrids. Biometric analysis showed that all the studied hybrids in many ways, such as: plant height, main panicle length, number of grains in a panicle, grain sterility, 
grain mass from the main panicle and from a plant surpassed not only the best parental forms, but also the first generation hybrids. The study of the inheritance of such traits as plants height, panicle length, the number of filled spikelets and grains on it, the mass of 1000 grains, etc., is of great importance in breeding work. The grain productivity of rice also depends on the number of spikelets in the panicle, the number of filled grains and their weight. Therefore, it is necessary to know the genetic mechanism of each of these traits and their interaction.

An important trait that is not a direct productivity element, but has a significant effect on plant resistance to lodging, is plant height. It is a genetically determined trait that can vary from growing conditions, and is also closely related to the number of nodes and the length of internodes $[4,6]$. Tall varieties are prone to lodging, although their plants are often capable of producing higher yields. In the lodged mass, a microclimate with high humidity is created, and therefore the caryopses begin to germinate, which reduces the technological and sowing qualities of seeds, and leads to yield losses. Over the past three decades, breeding work has been aimed at reducing the plant height, therefore, rice varieties developed during this period have short and strong stems, which contributes to high yields, lodging resistance, disease resistance and the formation of good quality. The coefficient of determination for plant height varied from complete dominance of 1,4 to overdominance of 32,3 (Table 1).

Table 1. Characteristic of $F_{1}$ and $F_{2}$ rice hybrids by the inheritance of morphological traits (2019)

\begin{tabular}{|c|c|c|c|c|c|c|c|c|c|c|}
\hline 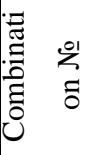 & Name & 客 & $\begin{array}{c}\text { Plant } \\
\text { height, } \\
\mathrm{cm}\end{array}$ & hp & 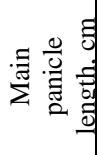 & hp & 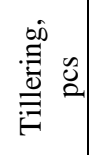 & hp & 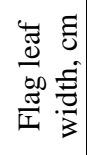 & hp \\
\hline \multirow[t]{4}{*}{3582} & VNIIR 6192 & 우 & 60,9 & & 14,4 & & 2,4 & & 1,0 & \\
\hline & KP 26-16 & 0 & 65,6 & & 17,2 & & 3,9 & & 2,0 & \\
\hline & VNIIR 6192/KP 26-16 & $F_{1}$ & 84,9 & & 17,1 & & 3,9 & & 2,0 & \\
\hline & VNIIR 6192/KP 26-16 & $\mathrm{F}_{2}$ & 100,4 & 9 & 19,7 & 0,9 & 2,5 & $-0,7$ & 1,05 & $-0,9$ \\
\hline \multirow[t]{4}{*}{3583} & Cammeo & q & 64,3 & & 16,2 & & 2 & & 1,0 & \\
\hline & KP 26-16 & $\overline{0}$ & 80,4 & & 14,1 & & 2,1 & & 1,4 & \\
\hline & Cammeo/KP26-16 & $\mathrm{F}_{1}$ & 80,5 & & 15,5 & & 3,0 & & 1,4 & \\
\hline & Cammeo/KP26-16 & $\mathrm{F}_{2}$ & 86,7 & 1,4 & 15,5 & 0,34 & 3,7 & $-0,25$ & 1,0 & $-0,85$ \\
\hline \multirow[t]{4}{*}{3606} & Cammeo & q & 68,6 & & 12,1 & & 3,0 & & 1,1 & \\
\hline & Magnat & $0^{\pi}$ & 66,6 & & 10,8 & & 2,0 & & 1,0 & \\
\hline & Cammeo /Magnat & $F_{1}$ & 80,5 & & 15,2 & & 3,0 & & 1,0 & \\
\hline & Cammeo /Magnat & $\mathrm{F}_{2}$ & 102,0 & 32,3 & 16,5 & 7,8 & 3,6 & $-2,2,7$ & 1,0 & 0,2 \\
\hline \multirow[t]{4}{*}{3607} & Cammeo & क & 79,7 & & 16,3 & & & & 1,69 & \\
\hline & Novator & $\hat{0}$ & 77,7 & & 16,0 & & & & 1,48 & \\
\hline & Cammeo/Novator & $F_{1}$ & 87,2 & & 16,7 & & & & 1,97 & \\
\hline & Cammeo/Novator & $\mathrm{F}_{2}$ & 99,7 & 19 & 15,4 & $-3,7$ & & 0,71 & 1,0 & -5 \\
\hline \multirow[t]{4}{*}{3618} & VNIIR40/4-1 & q & 72,3 & & 15,9 & & & & 1,29 & \\
\hline & Rongguang & $\hat{\sigma}$ & 73,0 & & 17,0 & & & & 0,92 & \\
\hline & VNIIR40/4-1/Rongguang & $\mathrm{F}_{1}$ & 78,6 & & 16,6 & & & & 1,2 & \\
\hline & VNIIR40/4-1/Rongguang & $\mathrm{F}_{2}$ & 84,9 & 28,7 & 16,4 & $-0,14$ & & 3,23 & 1,0 & $-0,52$ \\
\hline
\end{tabular}


In hybrids of the second generation, the variability of plant height was higher than in the first. The heterosis effect based on the panicle length was manifested in two combinations. The Cammeo / Magnat combination had the highest dominance coefficient -7.8. When comparing hybrids of the first and second generation, it can be concluded that the trait panicle length has a smaller range of variation than the plant height.

Rice among many grain crops has a higher ability to form productive stems. In the second generation, all hybrid combinations showed negative dominance from partial to overdominance.

On the basis of flag leaf width, negative overdominance was observed in the second generation in the Cammeo / Novator combination.

All the studied hybrid combinations showed overdominance in both the first and second generations in terms of the number of grains from the main panicle, the mass of grain from the main panicle, and the mass of grain per plant. Therefore, it is advisable to use them in breeding to develop high-yielding varieties.

Table 2. Characteristic of $F_{1}$ and $F_{2}$ rice hybrids by inheritance of traits controlling the yield (2019)

\begin{tabular}{|c|c|c|c|c|c|c|c|c|}
\hline 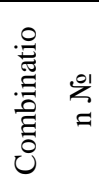 & Name & $\begin{array}{l}\text { ठे } \\
\text { हे }\end{array}$ & 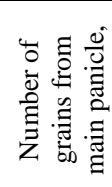 & $\approx$ & 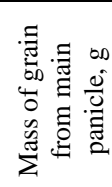 & $\approx$ & 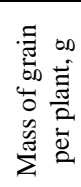 & $\cong$ \\
\hline 1 & 2 & 3 & 4 & 5 & 6 & 7 & 8 & 9 \\
\hline \multirow[t]{4}{*}{3582} & VNIIR 6192 & 우 & 62,5 & & 1,9 & & 3,6 & \\
\hline & KP 26-16 & $\hat{0}$ & 87,1 & & 1,8 & & 4,1 & \\
\hline & VNIIR 6192/KP26-16 & $\mathrm{F}_{1}$ & 89,5 & & 2,2 & & 4,6 & \\
\hline & VNIIR 6192/KP26-16 & $\mathrm{F}_{2}$ & 126,8 & 4,2 & 4,9 & 1,5 & 8,6 & 17,4 \\
\hline \multirow[t]{4}{*}{3583} & Cammeo & q & 83,2 & & 2,0 & & 3,6 & \\
\hline & KP 26-16 & $\hat{0}$ & 92,0 & & 1,8 & & 3,9 & \\
\hline & Cammeo/KP26-16 & $\mathrm{F}_{1}$ & 100,8 & & 2,7 & & 5,9 & \\
\hline & Cammeo/KP26-16 & $\mathrm{F}_{2}$ & 125,5 & 8,6 & 3,8 & 2,1 & 10,7 & 3,6 \\
\hline \multirow[t]{4}{*}{3606} & Cammeo & q & 77,9 & & 1,9 & & 4,1 & \\
\hline & Magnat & $\hat{\sigma}$ & 70,9 & & 1,7 & & 3,9 & \\
\hline & Cammeo /Magnat & $\mathrm{F}_{1}$ & 91,3 & & 2,1 & & 5,9 & \\
\hline & Cammeo /Magnat & $\mathrm{F}_{2}$ & 139,2 & 18,5 & 4,1 & 24,7 & 11,2 & 7,2 \\
\hline \multirow[t]{4}{*}{3607} & Cammeo & q & 79,2 & & 2,0 & & 4,0 & \\
\hline & Novator & $\hat{0}$ & 105,5 & & 2,1 & & 4,1 & \\
\hline & Cammeo/Novator & $\mathrm{F}_{1}$ & 121,8 & & 3,5 & & 7,5 & \\
\hline & Cammeo/Novator & $\mathrm{F}_{2}$ & 116,5 & 1,83 & 3,8 & 3,5 & 8,9 & 12,2 \\
\hline \multirow[t]{4}{*}{3618} & VNIIR40/4-1 & q & 80,5 & & 1,7 & & 3,5 & \\
\hline & Rongguang & $\hat{\sigma}$ & 86,3 & & 1,9 & & 3,1 & \\
\hline & VNIIR40/4-1/Rongguang & $\mathrm{F}_{1}$ & 88,0 & & 2,1 & & 4,0 & \\
\hline & VNIIR40/4-1|Rongguang & $\mathrm{F}_{2}$ & 112,4 & 10 & 3,9 & 3,4 & 8,8 & 3,4 \\
\hline
\end{tabular}




\section{Conclusions}

The average value of heterosis exceeded $100 \%$ in all the studied hybrid combinations in the first generation, for 5 traits, which makes it possible to predict the high productivity of each plant in the first generation by their values.

Hybrid combinations 3582, 3583, 3606, 3607, 3618 showed over-dominance by traits controlling the yield in the second generation, so they can be recommended to breeders for use for sowing in a breeding nursery, which significantly reduces the breeding process.

\section{References}

1. D. Brewbaker, Agricultural genetics, p. 237, (1966).

2. A. Smetanin Techniques of experimental work on breeding, seed production and quality control of rice seeds, 40, 1972

3. G. Los, Agricultural biology, 12,107-109, (1987)

4. V. Dzyuba, Rice Genetic, 285, (2004)

5. Zhuchenko, A.A. Adaptive system of plant breeding, 808, (2001)

6. V.Dzyuba, Multifactorial experiments and methods of biometric analysis of experimental data,76, (2007)

7. Kohlreyter, I. (1760), cited after Charles Darwin. Origin of Species, (1937)

8. V. Dzyuba, Grain economy of Russia, 3(21)-p.8 - 13, (2012

9. I. Chukhir, Rice growing, 250-252, (2016)

10. F.Eliot Plant breeding and cytogenetics, 447, (1961)

11. B. Griffing, Heredity, 10, 31-50, (1956)

12. H. Vistsuri, «Trop. Agr.», 3,164 - 171,( 1977) 